\title{
Effect of Marine Sterols on the Serum-Cholesterol Level in Mice
}

\author{
Akio Kanazawa, ${ }^{* 1}$ Shin-ichi Teshima, ${ }^{* 1}$ and Mitsuki Yoshora ${ }^{* 2}$ \\ (Received June 17, 1976)
}

\begin{abstract}
This study deals with the effect of the marine sterols, 24-methylcholest-7-enol, clerosterol, and 24-methylcholesta-7,22-dienol, on the serum cholesterol level in mice. When $0.1 \%$ levels of these sterols were added to the basal diet containing $1.0 \%$ cholesterol, the levels of liver lipids, liver cholesterol, and serum cholesterol increased. These results suggested that the sterols examined are hypercholesterolemic.
\end{abstract}

In a previous study, ${ }^{1)}$ it has been observed that 24-methylenecholesterol (24-methylenecholest-5-en-3 $\beta$-ol) and cholest-7-enol (cholest-7-en-3 $\beta$-ol) isolated from the marine mollusks lowered considerably the cholesterol level of serum and liver in the rats. This finding lets us to investigate further the hypocholesterolemic effect of other marine sterols. To this approach, in the present study the effect of 24-methylcholest-7-enol (24-methylcholest-7-en-3 $\beta$-ol), clerosterol (24S-24-ethylcholesta-5,25-dien-3 $\beta$-ol), and 24-methylcholesta-7,22-dienol (24-methylcholesta-7,22-dien-3 $\beta$-ol) on the cholesterol level in the mice was examined, and the hypocholesterolemic effect of sterols was discussed in relation to the chemical structure of sterol molecules.

\section{Materials and Methods}

Sterols used Cholesterol (cholest-5-en-3 $\beta$-ol) and ergosterol (24R-24-methylcholesta-5,7,22-trien-3 $\beta$-ol) were purchased from Nakarai Chemical Co. and purified by recrystallization from methanol. Cholesta-5,7-dienol (cholesta-5,7-dien-3 $\beta$-ol) was prepared from cholesterol in this laboratory. 24-Methylcholest-7-enol and 24-methylcholesta-7,22-dienol were isolated from a starfish, Acanthaster planci, and clerosterol was obtained from a green alga, Codium cylindricum. The isolation of these sterols was performed as follows: The lipids extracted with benzene or acetone from the starfish and marine alga were saponified with $10 \%$ potassium hydroxide in ethanol, and then the sterols were isolated from the unsaponifiable matters by alumina column chromatography with hexane-benzene. ${ }^{2}$ The sterols were acetylated with dry pyridine-acetic anhydride (1:1) and then subjected to column chromatography on a silver nitrate-impregnated silicic acid with hexane-benzene. ${ }^{3)}$ The repeated use of this column chromatography afforded pure steryl acetates. The hydrolysis of acetates with $5 \%$ potassium hydroxide followed by recrystallization from methanol gave pure sterols. The purity of these

*1 Faculty of Fisheries, University of Kagoshima, Kagoshima, Japan.（金沢昭夫 - 手岛新一：庇児島 大学水産学部)

*2 Faculty of Medicine, University of Kagoshima, Kagoshima, Japan.（吉岡满城：鹿児島大学医学部） 
sterols was checked by gas-liquid chromatography (GLC) on $1.5 \% \mathrm{OV}-17,{ }^{4 \prime}$ mass (MS), infrared absorption (IR), and nuclear magnetic resonance (NMR) spectrometries. 24Methylcholest-7-enol (m.p. $146^{\circ} \mathrm{C}$ ), MS m/e $400\left(\mathrm{M}^{+}\right)$; IR $800 \mathrm{~cm}^{-1}\left(\Delta^{7}\right) ; \operatorname{NMR}(\delta)$ $0.55\left(\mathrm{C}-18 \mathrm{CH}_{3}\right), 0.79\left(\mathrm{C}-19 \mathrm{CH}_{3}\right), 3.6(\mathrm{C}-3 \alpha \mathrm{H}), 5.15(\mathrm{C}-7 \mathrm{H})$ : clerosterol (m.p. $\left.130^{\circ} \mathrm{C}\right)$, MS m/e $412\left(\mathrm{M}^{+}\right)$; IR 1642 and $892 \mathrm{~cm}^{-1}\left(\Delta^{25}\right)$; NMR $(\delta) 0.65\left(\mathrm{C}-18 \mathrm{CH}_{3}\right), 0.98(\mathrm{C}-19$ $\left.\left.\mathrm{CH}_{3}\right), 3.2-3.5 、 \mathrm{C}-3 \alpha \mathrm{H}\right), 4.60-4.67(\mathrm{C}-262 \mathrm{H}), 5.24(\mathrm{C}-6 \mathrm{H}): 24-$ methylcholesta-7,22-dienol (m.p. 159-160' $\mathrm{C}$ ), MS m/e $398\left(\mathrm{M}^{+}\right)$; IR $970 \mathrm{~cm}^{-1}\left(\Delta^{22}\right)$; NMR $(\delta) 0.56\left(\mathrm{C}-18 \mathrm{CH}_{3}\right), 0.81$ $\left(\mathrm{C}-19 \mathrm{CH}_{3}\right), 3.60(\mathrm{C}-3 \alpha \mathrm{H}), 5.14-5.20(\mathrm{C}-7,22,233 \mathrm{H})$.

Test diets and feeding experiment The basal diet (diet A) was the same as used in the previous study ${ }^{11}$ and composed of the following ingredients ( $\mathrm{g} / 100 \mathrm{~g}$ of dry diet): sucrose 60 , casein 18.5 , soybean oil 4 , gelatin 5 , starch 5 , $\alpha$-cellulose 3 , McCallum salts 4 , sodium cholate 0.25 , vitamins 0.071 , and cholesterol 1 . The composition of test diets is shown in Table 1. Prior to the feeding experiment, the mice were maintained on the

Table 1. Composition of the test diets

\begin{tabular}{ll} 
Diet & Composition \\
A & Basal diet (containing 1.0\% cholesterol) \\
B & Basal diet $+0.1 \% 24$-methylcholest-7-enol \\
C & Basal diet $+0.1 \%$ clerosterol \\
D & Basal diet $+0.1 \%$ cholesta-5,7-dienol \\
E & Basal diet $+0.1 \%$ 24-methylcholesta-7,22-dienol \\
F & Basal diet $+0.1 \%$ ergosterol \\
\hline
\end{tabular}

$\operatorname{diet}$ A (containing $1.0 \%$ level of cholesterol) for 1 week, and then they were fed on the test diets (containing $1.0 \%$ level of cholesterol and $0.1 \%$ level of tested sterols) for successive 3 weeks as reported previously. ${ }^{11}$

Analytical methods The content of liver lipids was colorimetrically determined according to the BRAGDON oxidation method.s) The content of cholesterol in the liver and serum was measured by the method of SPERRY and WEBB. ${ }^{0}$ ?

\section{Results and Discussion}

All mice had a strong appetite for the test diets throughout the experimental period, however neither significant increase nor variation in the body weight was seen among the experimental groups owing to the use of adult individuals. Table 2 shows the liver weight and liver lipid concentration. Generally, a dietary supplement of cholesterol has been known to exert the increase in liver and serum cholesterol levels. In the present study, the liver lipid concentration was high in the mice fed on the diets $\mathrm{B}, \mathrm{C}$, and $\mathrm{E}$ as compared with that of the mice fed on the diet $A$, whereas the concentrations were low and almost similar levels in the experimental groups fed on the diets D and F, respectively. This 
Table 2. Liver weight and liver lipid concentration of the mice fed on the test diets

\begin{tabular}{cccc}
\hline Diet & $\begin{array}{c}\text { Liver weight } \\
(\mathrm{g})\end{array}$ & $\begin{array}{c}\text { Weight ratio } \\
\text { Liver/whole body*1 } \\
(\%)\end{array}$ & $\begin{array}{c}\text { Liver lipids } \\
(\mathrm{mg} / \mathrm{g} \text { tissue })\end{array}$ \\
\hline A & $1.56 \pm 0.09^{* 2}$ & 6.78 & $59.2 \pm 6.5^{* 2}$ \\
B & $1.91 \pm 0.21$ & 8.38 & $69.8 \pm 1.4$ \\
C & $1.49 \pm 0.05$ & 6.77 & $70.3 \pm 7.6$ \\
D & $2.25 \pm 0.17$ & 10.30 & $43.4 \pm 7.1$ \\
E & $1.87 \pm 0.18$ & 7.36 & $76.5 \pm 9.9$ \\
F & $1.65 \pm 0.10$ & 7.02 & $64.4 \pm 8.7$ \\
\hline
\end{tabular}

*1 The mice, weighing from 22 to $23 \mathrm{~g}$, were put into six experimental groups (each group, five mice) and fed on the diets. At the end of experimental period, the body weight gain was measured. However, no variation in the body weight was observed in every experimental group.

*2 S.E.

Table 3. Cholesterol level of the serum and liver of the mice fed on the test diets

\begin{tabular}{ccccc}
\hline Diet & \multicolumn{2}{c}{ Serum cholesterol } & \multicolumn{2}{c}{ Liver cholesterol } \\
& $\begin{array}{c}\text { Total } \\
(\mathrm{mg} / 100 \mathrm{~m} l)\end{array}$ & $\begin{array}{c}\text { Free } \\
(\mathrm{mg} / 100 \mathrm{ml})\end{array}$ & $\begin{array}{c}\text { Total } \\
(\mathrm{mg} / 100 \mathrm{~g})\end{array}$ & $\begin{array}{c}\text { Free } \\
(\mathrm{mg} / 100 \mathrm{~g})\end{array}$ \\
\hline A & $247 \pm 16.8^{*}$ & $44.6 \pm 4.1^{*}$ & $19.7 \pm 3.9^{*}$ & $2.7 \pm 0.3^{*}$ \\
B & $293 \pm 20.9$ & $59.2 \pm 6.0$ & $22.8 \pm 1.8$ & $3.9 \pm 0.4$ \\
C & $288 \pm 38.6$ & $58.0 \pm 8.2$ & $22.9 \pm 3.9$ & $3.2 \pm 0.3$ \\
D & $350 \pm 74.5$ & $120.5 \pm 31.0$ & $13.2 \pm 4.2$ & $3.5 \pm 0.6$ \\
E & $305 \pm 36.5$ & $63.5 \pm 8.1$ & $36.7 \pm 8.2$ & $4.1 \pm 0.3$ \\
F & $273 \pm 32.2$ & $58.4 \pm 6.7$ & $31.6 \pm 6.5$ & $3.6 \pm 0.5$ \\
\hline
\end{tabular}

*.E.

result indicated that the addition of 24-methylcholest-7-enol, clerosterol, and 24-methylcholesta-7,22-dienol elevated the liver lipid concentration, while cholesta-5,7-dienol lowered it. The weight ratio of liver to whole body was larger in the mice fed on the diets $B, D, E$, and $F$ than on the diet $A$, and the value of the mice fed on the diet $C$ was almost similar to that of the diet $\mathrm{A}$. The result suggested that all sterols examined caused the corpulence of liver considerably.

The serum and liver cholesterol concentrations of mice fed on the test diets are given in Table 3. As compared with the group fed on the diet A, the serum cholesterol concentration was markedly high in the mice fed on the diets $\mathrm{D}$ and $\mathrm{E}$, and it was slightly high in the groups fed on the diets B, C, and F. Fat from lowering the serum cholesterol level, all examined sterols, 24-methylcholest-7-enol, clerosterol, cholesta-5,7-dienol, 24-methylcholesta-7,22-dienol, and ergosterol exerted a hypercholesterolemic effect. As to the liver cholesterol concentration, every sterol except cholesta-5,7-dienol gave as much as or more high value than cholesterol. In the case of the mice fed on cholesta-5,7-dienol, the liver cholesterol level was lower than that of the group fed on the diet A containing cholesterol alone. 
Table 4. Effect of sterols on the serum cholesterol level in the mice and rats

\begin{tabular}{llll}
\hline \multicolumn{1}{c}{ Sterol } & Carbon number & Double bond & $\begin{array}{c}\text { Effect on serum } \\
\text { cholesterol level }\end{array}$ \\
\hline Cholesterol* $^{*}$ & 27 & 5 & + \\
Cholesta-5,7-dienol $^{\text {Cholest-7-enol* }}$ & 27 & 5,7 & + \\
24-Methylcholest-7-enol & 27 & 7 & - \\
24-Methylenecholesterol* & 28 & 7 & + \\
Brassicasterol* $^{*}$ & 28 & $5,24(28)$ & - \\
24-Methylcholesta-7,22-dienol & 28 & 5,22 & + \\
Ergosterol & 28 & 7,22 & + \\
$\beta$ 3-Sitosterol* & 28 & $5,7,22$ & + \\
Clerosterol $^{*}$ & 29 & 5 & + \\
\hline
\end{tabular}

+ , increase; - , decrease.

* Results about the rats which were cited from the data of TESHMA et al. (1974) ${ }^{1)}$

Table 4 summarizes the effect of various sterols on cholesterol levels in the mice and rats which has been examined by the present authors in this study or previously." Phytosterol such as $\beta$-sitosterol (24R-24-ethylcholest-5-en-3 $\beta$-ol) and campesterol (24R-24methylcholest-5-en-3 $\beta$-ol) are generally recognized as effective hypocholesterolemic substances. Some sterols are also known to exert such an effect to some extent, however there are few sterols with a hypocholesterolemic effect comparable to $\beta$-sitosterol. Previously, the authors have demonstrated that 24-methylenecholesterol and cholest-7-enol exerted a hypocholesterolemic effect in the rats comparable to $\beta$-sitosterol. ${ }^{11}$ Also, SUGANO ${ }^{7)}$ has reported that the hydrogenates of phytosterols showed a cholesterol lowering effect in the rats superior to $\beta$-sitosterol. Several workers have postulated that the difference in the hypocholesterolemic effect among sterols may be due to that of the chemical structures of sterol molecules. ${ }^{8,8)}$ In fact, as shown in Table 4, the effect of sterols on the serum cholesterol level varied according to the difference in both the sidechain length and the number and position of double bonds. Cholest-7-enol was hypocholesterolemic, but the introduction of additional methyl group (cf. 24-methylcholest7-enol), double bond at C-5 (cf. cholesta-5,7-dienol), and methyl group at C-24 together with double bonds at C-5, 22 (cf. ergosterol) or C-22 (cf. 24-methylcholesta-7,22-dienol) into this sterol molecule resulted in the loss of such an effect and exerted rather hypercholesterolemic effect. Campesterol has been conceived to has a cholesterol-lowering effect, however $\mathrm{C}_{38}-\Delta^{5}$-sterol with additional double bond at $\mathrm{C}-22$ (cf. brassicasterol) was not effective. While, $\mathrm{C}_{28}-\Delta^{5}$-sterol with additional methylene group at $\mathrm{C}-24$ (cf. 24 methylenecholesterol) exerted a marked hypocholesterolemic effect. Contrary to this, the introduction of methylene group at $\mathrm{C}-25$ (cf. clerosterol) to the molecule of $\beta$-sitosterol derived a hypercholesterolemic effect. KANEDA and $\mathrm{ARAI}^{9}$ ' have reported that the hypocholesterolemic effect of fucosterol (24S-24-ethylidenecholest-5-en-3 $\beta$-ol) was low. 
From these data, definite conclusion seems not to be withdrawn about the relationship between the chemical structure of sterols and their effect on the serum cholesterol level.

\section{Acknowledgements}

This work was supported in part by a grant from the Ministry of Education (Japan). The authors thank Mr. K. ODA for his technical assistance during this study.

\section{References}

1) S. Teshima, A. Kanazawa, M. Yoshioka and K. Kitahara: J. Sieroid Biochem., 5, 69-72 (1974).

2) S. Teshima and A. Kanazawa: This Bull., 37, 63-67 (1971).

3) S. Teshima, A. Kanazawa and T. Ando: Mem. Fac. Fish., Kagoshima Univ, 22, 1-6 (1973).

4) S. Teshima, A. Kanazawa and T. Ando: ibid., 20, 131-139 (1971).

5) J. H. Bragdon: In "Lipids and Steroid Hormones in Clinical Medicine," (ed. by F. W. SunderMAN), Lipincott. Philadelphya and Montreal, 1960, p. 9-14.

6) W. M. Sperry and M. WebB: J. Biol. Chem., 187, 97-106 (1950).

7) M. Sugano: KaGAKU to SElBUTSU, 14, 20-21 (1976).

8) E. Reiner, J. Topliff and J. D. Wood: Can. J. Biochem. Physiol, 40, 1401-1406 (1962).

9) T. Kaneda and K. Arai: This Bull, 30, 589-593 (1964). 